\title{
Mapping Of Air Pollution Using GIS: A Case Study of Hyderabad
}

\author{
Shiva Chandra Vaddiraju \\ Department of Civil Engineering, MVSR Engineering College, Nadergul, Hyderabad
}

Email: shivachandra135@gmail.com

\begin{abstract}
Air Pollution is a highly intensifying issue in Hyderabad which is engulfing almost each and every corner of the city mostly due to the human activities like rapid industrialization, increased vehicular activity leading to enormous amount of fuel consumption and all other activities like construction, power generation and rather all other anthropogenic activities. High rise constructions affect the flow of the air quantity resulting in exchange of air and scattering or spreading of pollutants. Cities encourage high human exposure to the harmful substances due to the escalated population and continuous vehicular activity. Air pollution is today's major problem in our modern society and several factors concur to create unfavourable conditions for air pollutant dispersion. The effect of air pollution on public health and environment depends on several factors like chemical composition of a particular pollutant, the level of concentration, health status of individuals and time of exposure.

Assessment of the impact of air quality effects on plants, animals, natural ecosystems, ecosystems and human health is important. Air quality management include monitoring and analysis of pollutant concentration, spatial distribution of pollutant concentration, and assessment of no. of environmental factors affected by air pollutants, preparation of health risk map. GIS is very useful for assessment of air quality. GIS has been used in the present study to map the various pollution data and analyze the areas which are most affected by what type of pollutant and subsequent conclusions drawn for making the Hyderabad a safe and sustainable area to live in.
\end{abstract}

Index Terms- GIS, Air Pollution, Monitoring

\section{INTRODUCTION}

The quality of the air is very vital to our health and to all other living beings. The contamination in air can cause various health hazards and there is a major risk of chronic and respiratory diseases, but the monitoring of the air quality contamination is often termed as difficult. Geo spatial Technologies operate and manage spatial and statistical data and provide us with the results giving us the correlation between the air quality and human health. So Geo spatial Technologies can be widely used for monitoring air quality.

There are already signs of distress and bother about this contamination of air quality mostly in cities and urban areas and is getting worldwide importance. The proper quality sampling at each particular location can be an issue therefore it is very important to have a suitable process to calculate or predict the data for the area under study.

Hyderabad has the worst air quality as far as pollution by Particulate Matter is concerned among cities in south and west India. Hyderabad had the highest number of red days as opposed to western and southern cities as per the statistics of Central Pollution Control Board. The days which have greater levels of PM2.5 in the air are considered as Red days.PM2.5 refers to particles that are less than 2.5 micrometers in diameter, and is said to be the most dangerous of airborne pollutants as they are able to enter the lungs.
Though PM 2.5 levels in Hyderabad are alarming, the annual average is being maintained as per Pollution Control Board (PCB).The PCB of Telangana has 19 manual air quality stations which measures pollution across Hyderabad.

"Air quality once lost cannot be restored within a short period of time. Air Pollutants are harmful to everyone, not just to people who are susceptible to breathing problems." The decrease in green spaces and the increase in concrete cover also play a major role in the deterioration of air quality. [1]

According to Environmentalist Dr Subba Rao, "Open spaces are covered in concrete, and we are now gripped by air pollution. Green Cover act as buffer zones and they help reduce the spread of gaseous pollutants. Dust can also settle on their leaves." [2].Development of industries in every nook and corner of the city is only going to lead to a further increase in the particulate matter. Creating awareness among the public is the only solution to this problem. Various studies has been carried out by Awkash Kumar et al(2016)[3], Mamta Pandey et al(2013)[4], E.Bozyazi et al(2000)[5].

\section{STUDY AREA}

Hyderabad, a 400 years old city, is the state capital of Telangana, India, with a population of around one crore. The twin cities of Hyderabad, Secunderabad 


\section{E-ISSN: 2321-9637 \\ Available online at www.ijrat.org}

and neighbouring ten municipalities together form Hyderabad Urban Development Authority (HUDA), a major high-tech centre, with increasing economic activity. Coordinates: $17^{\circ} 23^{\prime} 13^{\prime \prime} \mathbf{N} \&$ $\mathbf{7 8}^{\circ} 29^{\prime} 30^{\prime \prime}$ E.

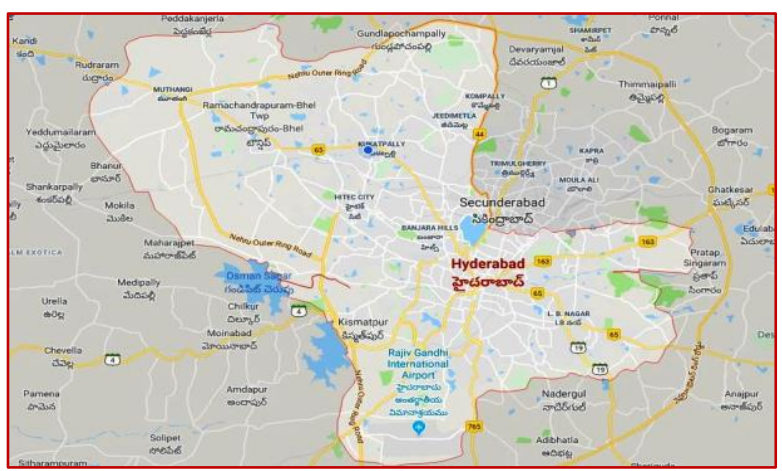

Fig.1: Google map of Hyderabad

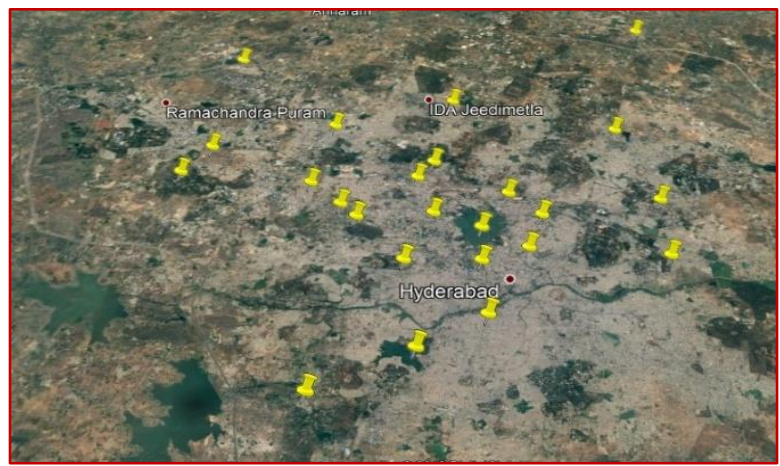

Fig 2: Google image showing the sampling locations

\section{METHODOLOGY}

\section{Collection of air quality data:}

The air quality data is collected from the Telangana pollution control board and entered into the excel sheets. The areas of sampling for air pollution are around 24 of which some sampling areas take the readings of only few gases that have an effect on the air quality. The data entered in the excel sheet along with the latitude and longitudinal details of the sampling stations.

\section{Adding the data to the GIS software:}

The GIS software used here in this project is ARC GIS.ARC Map is used for the further procedure of mapping. The excel sheet of the air quality data with the latitude and longitudinal details is added to the software and the file is right clicked to give the $\mathrm{X}$-axis for longitudes and $\mathrm{Y}$ - axis for the latitudes which creates a point file locating the sampling stations in the form of points features.

Creation a shape files and thiessen polygons:
The added point view file is converted into a shape file forming polygons of sampling stations but the air quality data is taken at a particular place so to consider the value taken for a pollutant for the entire region thiessen polygons are created which assigns the value to the entire polygon which is near to it making the analysis easy and to compare the variation.

\section{Creation of Thematic maps:}

Thematic maps are prepared for the pollutants under study. These maps helps in comparing the variation of a pollutant through a period of three years and helps to analyse the reason of increase in value or decrease and giving an opportunity for the decision makers to identify ways in which the increasing pollutant value can be controlled.

\section{RESULTS AND DISCUSSIONS}

It is clearly observed that all types of pollutants are in increasing trend across Hyderabad except in few pockets. Various queries are performed in GIS to identify the localities which are beyond the permissible limits defined by WHO.

Guidelines Values prescribed by WHO: PM10 $20 \mu \mathrm{g} / \mathrm{m3}$ annual mean, NO2 - 40 $\mathrm{gg} / \mathrm{m3}$, SO2 $20 \mu \mathrm{g} / \mathrm{m} 3$

SO2: $\mathrm{SO} 2$ concentration is within the defined limits, but it is observed that it is increasing yearly.

NO2: NO2 concentration is within the limits in most of the localities except HCU, Sanathnagar, Zoo Park and Pashamylaram Areas.

PM10:PM10 concentration is much higher than the WHO prescribed values of the order of 3 to 8 times which is highly alarming.

Identifying which localities are within limits and which crossed limits is much easier using GIS when compared to conventional systems. .

Various queries are performed using ARCGIS and the results are presented in map form for better understanding to Administrators and public.

Table 1: Hyderabad Ambient Air Quality Monitoring - Average values of $\mathrm{SO}_{2}$ in $\mu \mathrm{g} / \mathrm{m}^{3}$

\begin{tabular}{|c|l|c|c|c|}
\hline S.No & Sampling Location & $\mathbf{2 0 1 6}$ & $\mathbf{2 0 1 7}$ & $\mathbf{2 0 1 8}$ \\
\hline 1 & $\begin{array}{l}\text { Balanagar, CITD } \\
\text { office }\end{array}$ & 4.73 & 5 & 4.8 \\
\hline 2 & $\begin{array}{l}\text { Uppal, Modern food } \\
\text { Industry, IDA }\end{array}$ & 4.78 & 4.92 & 4.8 \\
\hline 3 & $\begin{array}{l}\text { Jubilee Hills, Police } \\
\text { station }\end{array}$ & 4.68 & 5.29 & 5 \\
\hline 4 & Paradise, HMWS & 4.7 & 4.73 & 4.5 \\
\hline
\end{tabular}




\begin{tabular}{|c|l|c|c|c|} 
& \&SB Pump house & & & \\
\hline 5 & $\begin{array}{l}\text { Charminar, TSRTC } \\
\text { bus station }\end{array}$ & 4.71 & 4.86 & 4.8 \\
\hline 6 & $\begin{array}{l}\text { Jeedimetla, Industrial } \\
\text { Association building }\end{array}$ & 5 & 5.4 & 4.9 \\
\hline & $\begin{array}{l}\text { Buddha Poornima } \\
\text { Project office, Tank } \\
\text { Bund }\end{array}$ & 4.51 & 4.7 & 4.6 \\
\hline 8 & MGBS, Bus stand & 4.59 & 4.9 & 4.7 \\
\hline 9 & $\begin{array}{l}\text { Chikkadapally, } \\
\text { Lepakshi Emporium }\end{array}$ & 4.69 & 4.85 & 4.6 \\
\hline 10 & $\begin{array}{l}\text { Langar House, Police } \\
\text { Station }\end{array}$ & 4.61 & 4.87 & 5.1 \\
\hline 11 & $\begin{array}{l}\text { Madhapur, Shilpa } \\
\text { Kalavedika }\end{array}$ & 4.49 & 4.87 & 4.7 \\
\hline 12 & $\begin{array}{l}\text { Shameerpet, MRO } \\
\text { office }\end{array}$ & 4.42 & 4.65 & 4.5 \\
\hline 13 & Kukatpally, JNTU & 4.78 & 5.3 & 5 \\
\hline 14 & $\begin{array}{l}\text { Sainikpuri, MRO } \\
\text { office }\end{array}$ & 4.53 & 4.61 & 4.7 \\
\hline 15 & $\begin{array}{l}\text { Rajendranagar, } \\
\text { NGRAU }\end{array}$ & 4.3 & 4.58 & 4.5 \\
\hline 16 & $\begin{array}{l}\text { Nacharam, Police } \\
\text { station }\end{array}$ & 4.73 & 5.04 & 4.6 \\
\hline 17 & Abids, Police station & 4.62 & 4.8 & 4.7 \\
\hline 18 & $\begin{array}{l}\text { KBRN Park, DFO } \\
\text { office }\end{array}$ & 4.36 & 4.73 & 4.6 \\
\hline 19 & HCU & 9.03 & 8.39 & 10.7 \\
\hline 20 & Sanathnagar & 9.05 & 6.52 & 17 \\
\hline 21 & Zoopark & 7.86 & 11.34 & 6.4 \\
\hline 22 & Pashamylaram & 12.77 & 9.19 & 13.1 \\
\hline 23 & Bollaram, CAAQMS & NA & 33.23 & 15.6 \\
\hline 24 & ICRISAT & NA & 13.5 & 17.8 \\
\hline & & & \\
\hline
\end{tabular}

Table 2: Hyderabad Ambient Air Quality Monitoring - Average values of $\mathrm{NO}_{\mathrm{X}}$ in $\mu \mathrm{g} / \mathrm{m}^{3}$

\begin{tabular}{|c|l|c|c|c|}
\hline S.No & Sampling Location & $\mathbf{2 0 1 6}$ & $\mathbf{2 0 1 7}$ & $\mathbf{2 0 1 8}$ \\
\hline 1 & $\begin{array}{l}\text { Balanagar, CITD } \\
\text { office }\end{array}$ & 31.13 & 37.34 & 40.5 \\
\hline 2 & $\begin{array}{l}\text { Uppal, Modern food } \\
\text { Industry, IDA }\end{array}$ & 28.45 & 34.38 & 33.9 \\
\hline 3 & $\begin{array}{l}\text { Jubilee Hills, Police } \\
\text { station }\end{array}$ & 28.12 & 27.93 & 30.6 \\
\hline 4 & $\begin{array}{l}\text { Paradise, HMWS } \\
\text { \&SB Pump house }\end{array}$ & 28.88 & 39.2 & 35.9 \\
\hline 5 & $\begin{array}{l}\text { Charminar, TSRTC } \\
\text { bus station }\end{array}$ & 30.37 & 29.18 & 33.8 \\
\hline 6 & $\begin{array}{l}\text { Jeedimetla, Industrial } \\
\text { Association Building }\end{array}$ & 27.95 & 31.13 & 35 \\
\hline 7 & $\begin{array}{l}\text { Buddha Purnima } \\
\text { Project office, Tank }\end{array}$ & 20.61 & 20.98 & 23.5 \\
\hline
\end{tabular}

\begin{tabular}{|c|l|c|c|c|}
\hline & Bund & & & \\
\hline 8 & MGBS, Bus stand & 20.85 & 22.1 & 24.5 \\
\hline 9 & $\begin{array}{l}\text { Chikkadapally, } \\
\text { Lepakshi Emporium }\end{array}$ & 22.35 & 23.76 & 25.5 \\
\hline 10 & $\begin{array}{l}\text { Langar House, Police } \\
\text { Station }\end{array}$ & 22.94 & 28.53 & 28.6 \\
\hline 11 & $\begin{array}{l}\text { Madhapur, Shilpa } \\
\text { Kalavedika }\end{array}$ & 18.98 & 22.67 & 24.5 \\
\hline 12 & $\begin{array}{l}\text { Shameerpet, MRO } \\
\text { office }\end{array}$ & 17.1 & 18.11 & 21 \\
\hline 13 & Kukatpally, JNTU & 26.47 & 34.19 & 38.1 \\
\hline 14 & $\begin{array}{l}\text { Sainikpuri, MRO } \\
\text { office }\end{array}$ & 17.81 & 18.58 & 18.4 \\
\hline 15 & $\begin{array}{l}\text { Rajendranagar, } \\
\text { NGRAU }\end{array}$ & 15.83 & 15.56 & 17.8 \\
\hline 16 & $\begin{array}{l}\text { Nacharam, Police } \\
\text { station }\end{array}$ & 23.27 & 23.07 & 25.1 \\
\hline 17 & Abids, Police station & 24.17 & 24.68 & 25.4 \\
\hline 18 & $\begin{array}{l}\text { KBRN Park, DFO } \\
\text { office }\end{array}$ & 18.05 & 17.99 & 23.5 \\
\hline 19 & HCU & 69.83 & 38.33 & 66.4 \\
\hline 20 & Sanathnagar & 43.58 & 45.23 & 71.3 \\
\hline 21 & Zoopark & 41 & 39.84 & 74.4 \\
\hline 22 & Pashamylaram & 46.42 & 45.07 & 84.7 \\
\hline 23 & Bollaram, CAAQMS & 65.42 & 29.33 & 37.7 \\
\hline 24 & ICRISAT & 23.23 & 21.85 & 32.6 \\
\hline
\end{tabular}

Table 3: Hyderabad Ambient Air Quality Monitoring - Average values of $\mathrm{PM}_{10}$ in $\mu \mathrm{g} / \mathrm{m}^{3}$

\begin{tabular}{|c|l|c|c|c|}
\hline S.No & Sampling Location & $\mathbf{2 0 1 6}$ & $\mathbf{2 0 1 7}$ & $\mathbf{2 0 1 8}$ \\
\hline 1 & $\begin{array}{l}\text { Balanagar, CITD } \\
\text { office }\end{array}$ & 131 & 146 & 162 \\
\hline 2 & $\begin{array}{l}\text { Uppal, Modern food } \\
\text { Industry, IDA }\end{array}$ & 96 & 115 & 159 \\
\hline 3 & $\begin{array}{l}\text { Jubilee Hills, Police } \\
\text { station }\end{array}$ & 108 & 127 & 143 \\
\hline 4 & $\begin{array}{l}\text { Paradise, HMWS } \\
\text { \&SB Pump house }\end{array}$ & 121 & 112 & 144 \\
\hline 5 & $\begin{array}{l}\text { Charminar, TSRTC } \\
\text { bus station }\end{array}$ & 108 & 122 & 165 \\
\hline 6 & $\begin{array}{l}\text { Jeedimetla, Industrial } \\
\text { Association building }\end{array}$ & 115 & 133 & 149 \\
\hline 7 & $\begin{array}{l}\text { Buddha Purnima } \\
\text { Project office }\end{array}$ & 64 & 69 & 89 \\
\hline 8 & MGBS, Bus stand & 76 & 101 & 107 \\
\hline 9 & $\begin{array}{l}\text { Chikkadapally, } \\
\text { Lepakshi Emporium }\end{array}$ & 82 & 84 & 102 \\
\hline 10 & $\begin{array}{l}\text { Langar House, Police } \\
\text { Station }\end{array}$ & 89 & 102 & 126 \\
\hline 11 & $\begin{array}{l}\text { Madhapur, Shilpa } \\
\text { Kalavedika }\end{array}$ & 75 & 86 & 121 \\
\hline
\end{tabular}


International Journal of Research in Advent Technology, Vol.7, No.5, May 2019

E-ISSN: 2321-9637

Available online at www.ijrat.org

\begin{tabular}{|c|l|c|c|c|}
12 & $\begin{array}{l}\text { Shameerpet, MRO } \\
\text { office }\end{array}$ & 73 & 76 & 63 \\
\hline 13 & Kukatpally, JNTU & 89 & 108 & 160 \\
\hline 14 & $\begin{array}{l}\text { Sainikpuri, MRO } \\
\text { office }\end{array}$ & 81 & 91 & 93 \\
15 & $\begin{array}{l}\text { Rajendranagar, } \\
\text { NGRAU }\end{array}$ & 68 & 64 & 61 \\
\hline 16 & $\begin{array}{l}\text { Nacharam, Police } \\
\text { station }\end{array}$ & 112 & 103 & 124 \\
\hline 17 & Abids, Police station & 107 & 106 & 141 \\
\hline 18 & $\begin{array}{l}\text { KBRN Park, DFO } \\
\text { office }\end{array}$ & 58 & 70 & 104 \\
\hline 19 & HCU & 111 & 92 & 147 \\
\hline 20 & Zoopark & 75 & 109 & 182 \\
\hline 21 & Pashamylaram & 111 & 103 & 162 \\
\hline 22 & Bollaram, CAAQMS & 90 & 117 & 149 \\
\hline 23 & ICRISAT & NA & 101 & 161 \\
\hline
\end{tabular}

\section{GIS Maps}

GIS Maps are prepared for $\mathrm{PM}_{10}, \mathrm{NO}_{2}, \mathrm{SO}_{2}$ for the years 2016, 2017 and 2018 and identified the localities in which pollution standards are beyond permissible limits.

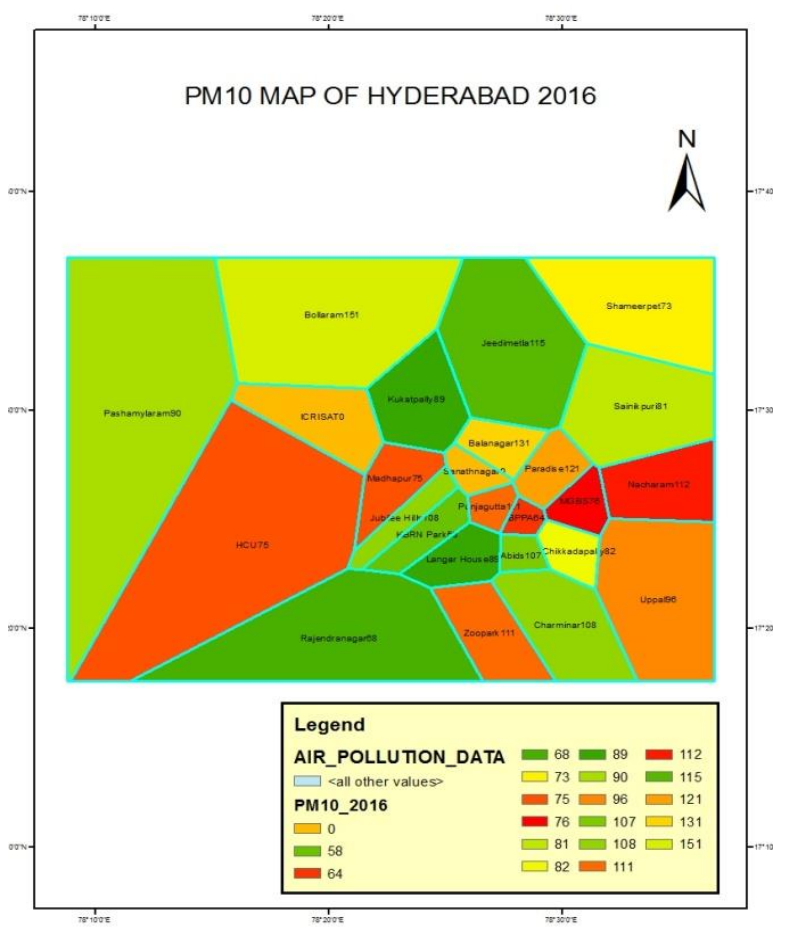

Fig 3:GIS Map highlighting the localities having $\mathrm{PM}_{10}$ value greater than $20 \mu \mathrm{g} / \mathrm{m}^{3}$ in 2016

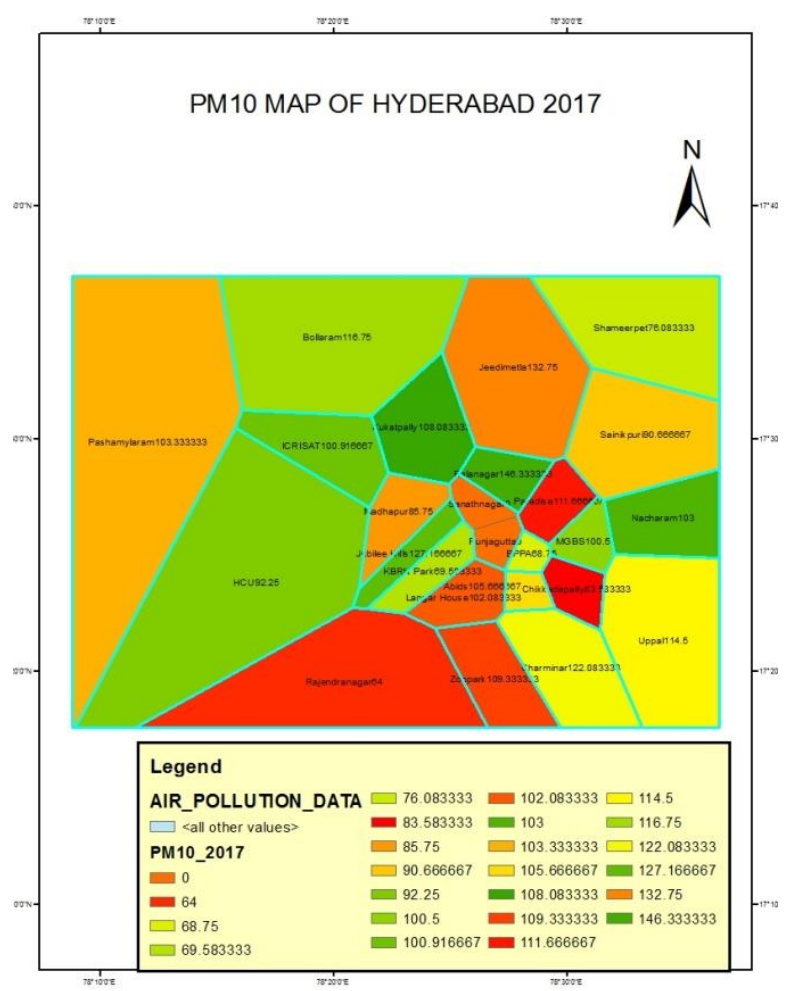

Fig 4: GIS Map highlighting the localities having $\mathrm{PM}_{10}$ value greater than $20 \mu \mathrm{g} / \mathrm{m}^{3}$ in 2017

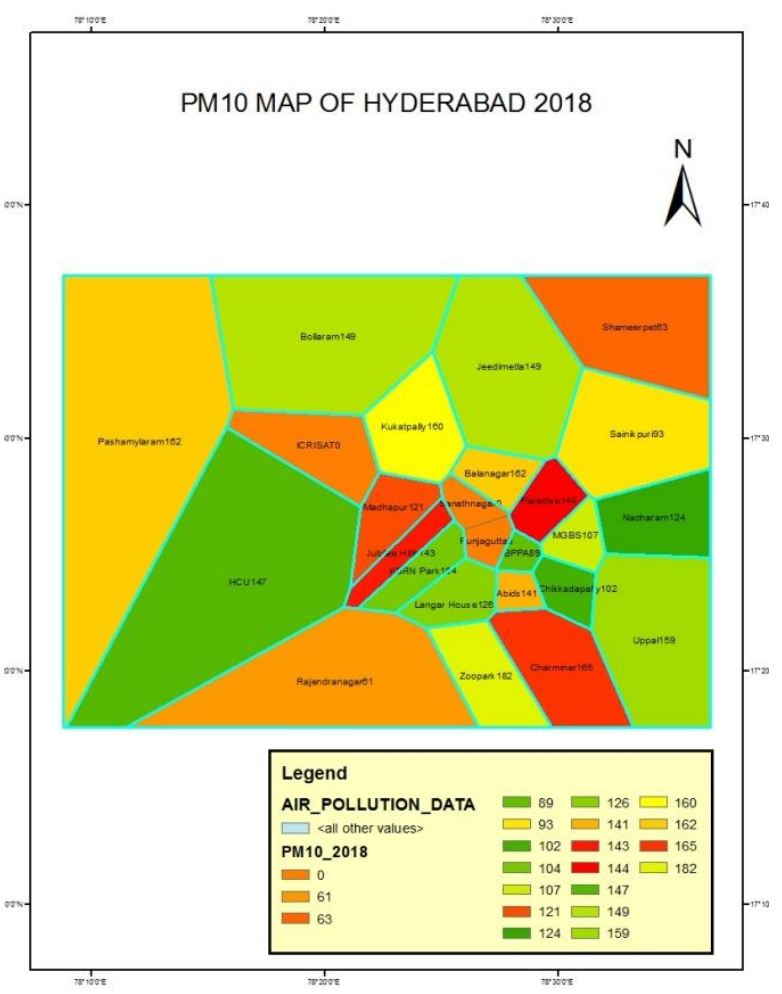

Fig 5: GIS Map highlighting the localities having PM10 value greater than $20 \mu \mathrm{g} / \mathrm{m}^{3}$ in 2018 
International Journal of Research in Advent Technology, Vol.7, No.5, May 2019

E-ISSN: 2321-9637

Available online at www.ijrat.org

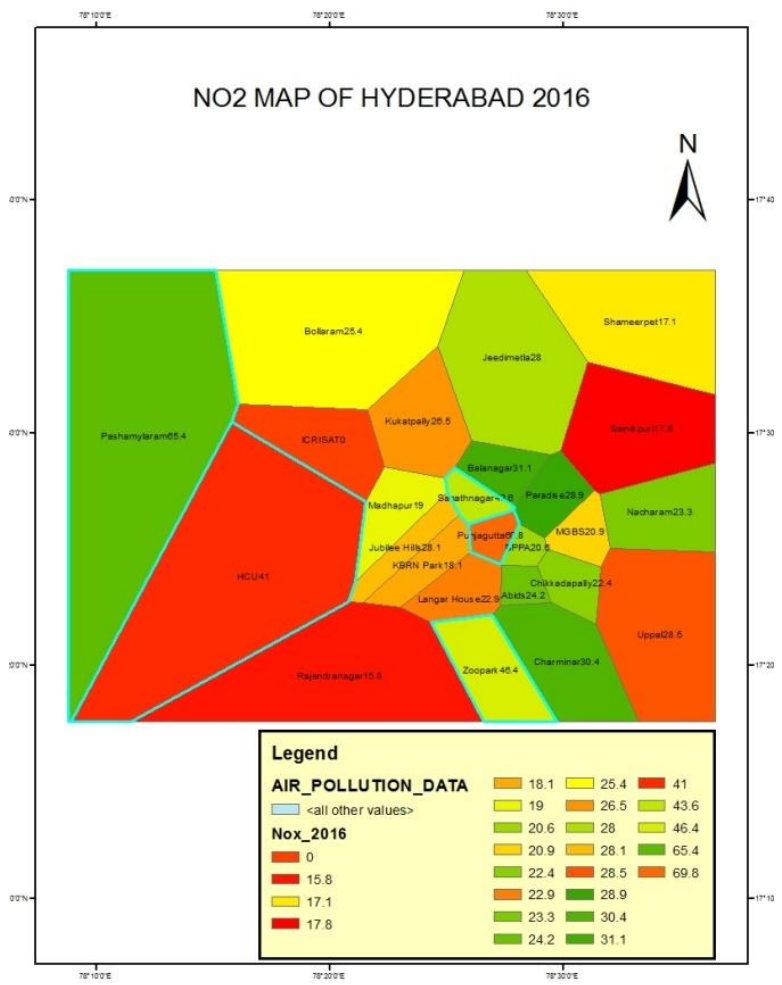

Fig 6: GIS Map highlighting the localities having $\mathrm{NO}_{2}$ value greater than $40 \mu \mathrm{g} / \mathrm{m}^{3}$ in 2016

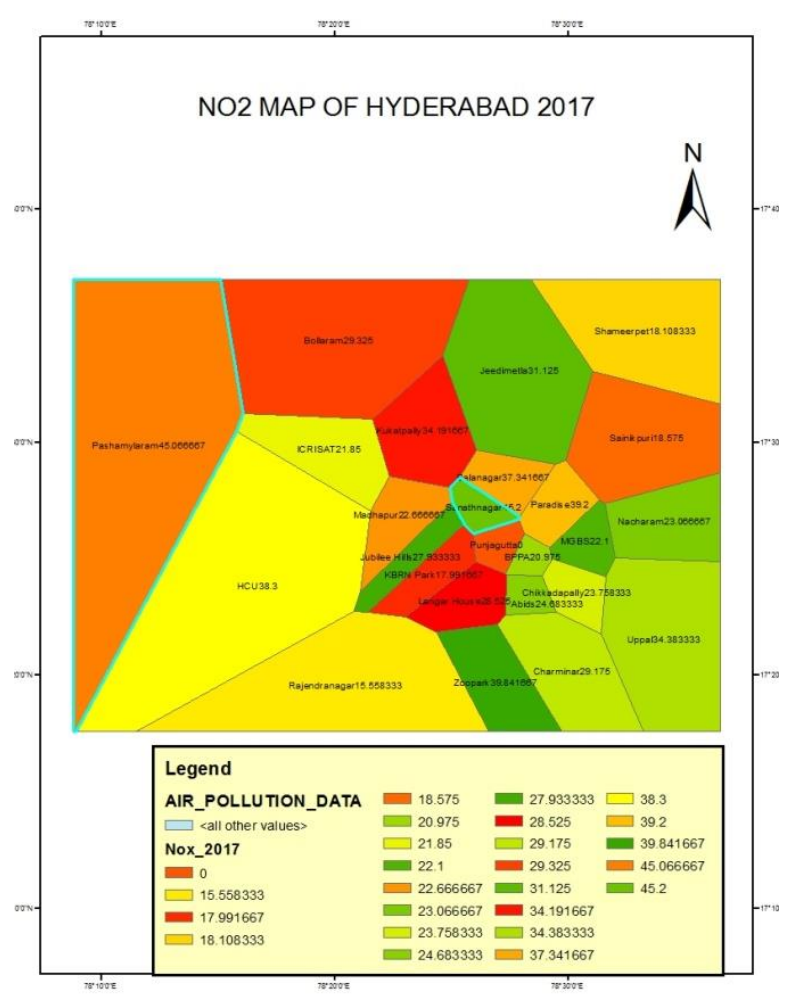

Fig 7:GIS Map highlighting the localities having $\mathrm{NO}_{2}$ value greater than $40 \mu \mathrm{g} / \mathrm{m}^{3}$ in 2017

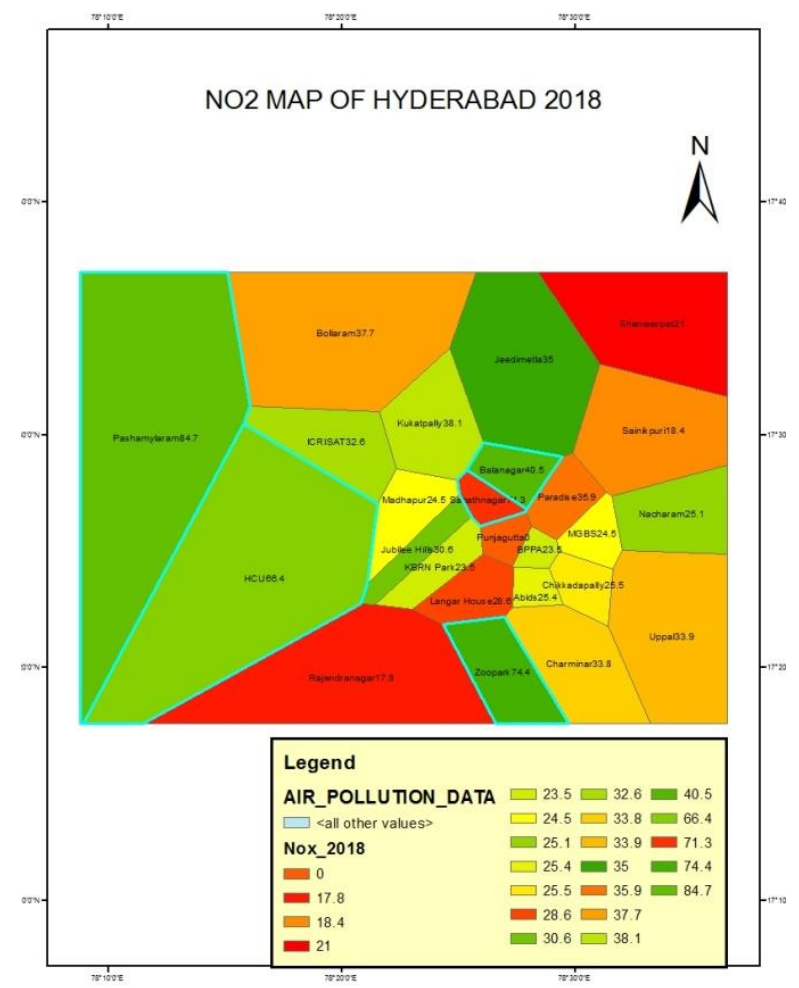

Fig 8:GIS Map highlighting the localities having $\mathrm{NO}_{2}$ value greater than $40 \mu \mathrm{g} / \mathrm{m}^{3}$ in 2018

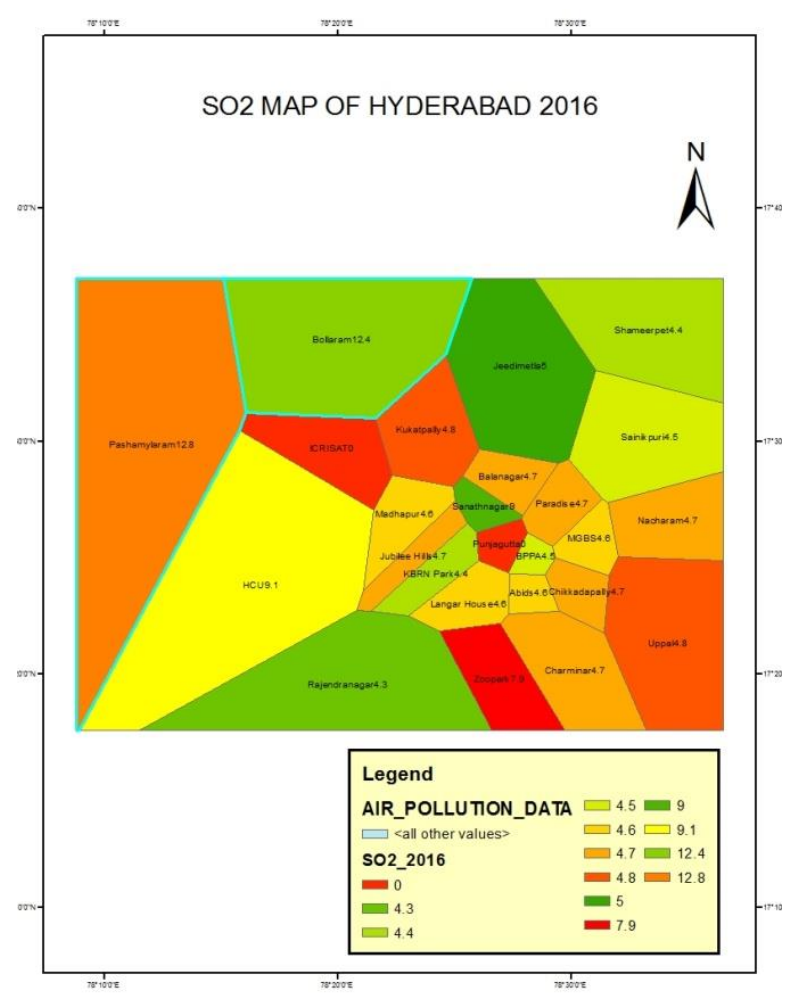

Fig 9: GIS Map highlighting the localities having $\mathrm{SO}_{2}$ value greater than $10 \mu \mathrm{g} / \mathrm{m}^{3}$ in 2016 
International Journal of Research in Advent Technology, Vol.7, No.5, May 2019

E-ISSN: 2321-9637

Available online at www.ijrat.org

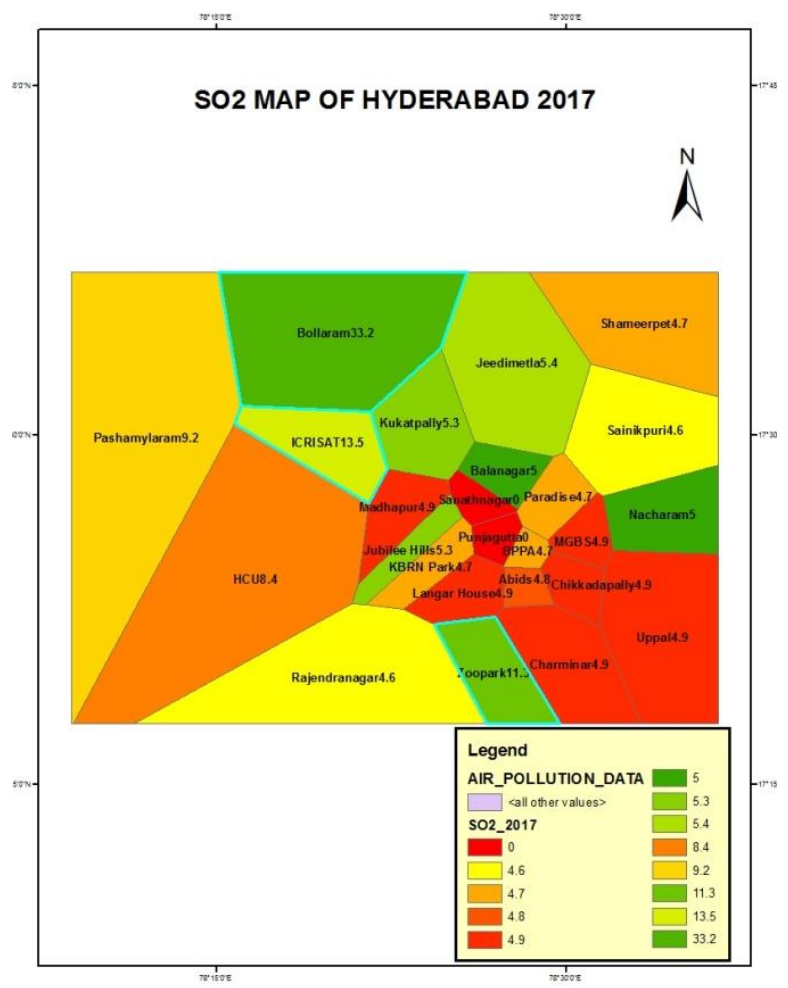

Fig 10: GIS Map highlighting the localities having $\mathrm{NO}_{2}$ value greater than $10 \mu \mathrm{g} / \mathrm{m}^{3}$ in 2017

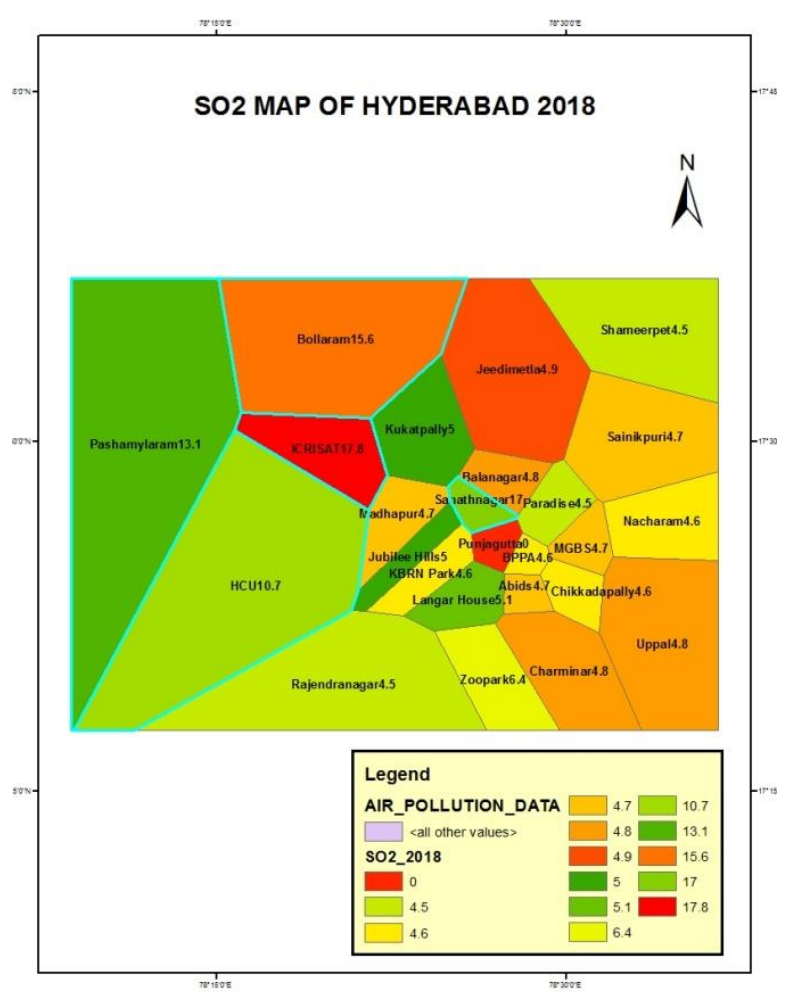

Fig 11: GIS Map highlighting the localities having $\mathrm{SO}_{2}$ value greater than $10 \mu \mathrm{g} / \mathrm{m}^{3}$ in 2018

\section{CONCLUSION}

- Air pollution is in an increasing trend in the city of Hyderabad.

- Conventional monitoring and assessment of air quality is a tedious process and hard to understand by many people.

- GIS helps in preparing maps of variations of various pollutants and present it in a easily understandable manner to even general public.

- It becomes very easy for the decision makers to identify which localities are affected by which type of pollutant and decide upon suitable remedial measures.

- In the present study variations of Particulate Matter, SO2, NOx, has been studied and thematic maps are prepared using GIS for better understanding and further analysis.

\section{ACKNOWLEDGEMENTS}

The author would like to express his thanks to Telangana Pollution Control Board for providing data.

\section{REFERENCES}

[1] R.S.Kanakiya, S.K.Singh, U.Shah GIS Application for Spatial and Temporal Analysis of the Air Pollutants in Urban Area, International Journal of Advanced Remote Sensing and GIS 2015, Volume4, Issue 1, pp.1120-1129.

[2] [www.deccanchronicle.com/nation/currentaffairs/281017.

[3] Awkash Kumar, Indrani Gupta, Jørgen Brandt, Rakesh Kumar, Anil Kumar Dikshit \& Rashmi S. Patil (2016) Air quality mapping using GIS and Economic evaluation of health impact for Mumbai City, India, Journal of the Air \& Waste Management Association, 66:5, 470-481.

[4] Mamta Pandey et al; Analysis \& Application of GIS Based Air Quality Monitoring- State of Art, International Journal of Engineering Research \& Technology (IJERT), Vol. 2 Issue 12, December -2013 .

[5] E.Bozyazi et al, Analysis and mapping of air Pollution using a GIS approach: A case study of Istanbul. 